\title{
STRENGTH AND TOUGHNESS OF CERAMIC-METAL COMPOSITES PREPARED BY REACTIVE HOT PRESSING
}

Donald T. Ellerby and Ronald E. Loehman

Sandia National Laboratories

William G. Fahrenholtz

1001 University Blvd. SE, Suite 100

Ceramic Engineering Department

Albuquerque, NM 87106

University of Missouri-Rolla

Rolla, MO 65409

\section{ABSTRACT}

Metal-reinforced $\mathrm{Al}_{2} \mathrm{O}_{3}$-matrix composites were prepared using reactive hot pressing. The volume fraction of the reinforcing phase was controlled by the stoichiometry of the particular displacement reaction used. Dense $\mathrm{Al}_{2} \mathrm{O}_{3}-\mathrm{Ni}$ and $\mathrm{Al}_{2} \mathrm{O}_{3}-\mathrm{Nb}$ composites were fabricated using this technique. The best combination of strength, $610 \mathrm{MPa}$, and toughness, $12 \mathrm{MPam}^{1 / 2}$, was found for the $\mathrm{Al}_{2} \mathrm{O}_{3}-\mathrm{Ni}$. composites. Indentation cracks and fracture surfaces showed evidence of ductile deformation of the $\mathrm{Ni}$ phase. The $\mathrm{Al}_{2} \mathrm{O}_{3}-\mathrm{Nb}$ composites had high strength, but the toughness was lower than expected due to the poor bonding between the $\mathrm{Nb}$ and $\mathrm{Al}_{2} \mathrm{O}_{3}$ phases.

\section{INTRODUCTION}

Metal-reinforced ceramics offer the potential for improved strength and toughness compared to monolithic ceramics. These composites combine the high elastic modulus, hardness and low density of the ceramic phase with the high ductility of the metallic phase to produce composites with properties unattainable from either pure ceramics or pure metals. Of the ceramic-metal systems studied, $\mathrm{Al}_{2} \mathrm{O}_{3}-\mathrm{Al}$ composites have probably received the most attention. A number of processing techniques have been developed to fabricate $\mathrm{Al}_{2} \mathrm{O}_{3}-\mathrm{Al}$ composites, including directed metal oxidation [1], reactive metal penetration [2], displacement reactions between $\mathrm{Al}$ and $\mathrm{SiO}_{2}$ [3], and the pressure infiltration of $\mathrm{Al}$ into porous $\mathrm{Al}_{2} \mathrm{O}_{3}$ preforms. [4] The most significant factor limiting the use of $\mathrm{Al}_{2} \mathrm{O}_{3}-\mathrm{Al}$ composites is its low use temperature due to the relatively low melting temperature of aluminum. Many of the potential applications for ceramic-metal composites require higher use temperatures than are attainable in the $\mathrm{Al}_{2} \mathrm{O}_{3}-\mathrm{Al}$ 


\section{DISCLAIMER}

This report was prepared as an account of work sponsored by an agency of the United States Government. Neither the United States Government nor any agency thereof, nor any of their employees, make any warranty, express or implied, or assumes any legal liability or responsibility for the accuracy, completeness, or usefulness of any information, apparatus, product, or process disclosed, or represents that its use would not infringe privately owned rights. Reference herein to any specific commercial product, process, or service by trade name, trademark, manufacturer, or otherwise does not necessarily constitute or imply its endorsement, recommendation, or favoring by the United States Government or any agency thereof. The views and opinions of authors expressed herein do not necessarily state or reflect those of the United States Government or any agency thereof. 


\section{DISCLAIMER}

Portions of this document may be illegible in electronic image products. Images are produced from the best available original document. 
system. Thus, there is a need for processing techniques to make composites that contain more refractory metals.

Many other reinforcements have been investigated for $\mathrm{Al}_{2} \mathrm{O}_{3}$-matrix composites, including $\mathrm{Ni}$ and $\mathrm{Nb} . \mathrm{Al}_{2} \mathrm{O}_{3}-\mathrm{Ni}$ composites have received considerable attention [5-12]. A number of processing techniques have been developed to form $\mathrm{Al}_{2} \mathrm{O}_{3}-\mathrm{Ni}$ composites, including free sintering of $\mathrm{Ni}$ and alumina powders [5], displacement reactions between $\mathrm{Al}$ and $\mathrm{NiO}$ [8], and reduction of $\mathrm{NiO}$ or $\mathrm{NiAl}_{2} \mathrm{O}_{4}$. $[6,7,10,11]$ Free sintering routes are complicated by the tendency of $\mathrm{Ni}$ flow out of $\mathrm{Al}_{2} \mathrm{O}_{3}$ powder compacts during sintering.[5] Fabrication of $\mathrm{Al}_{2} \mathrm{O}_{3}-\mathrm{Ni}$ composites by the reduction of $\mathrm{NiO}$ or $\mathrm{NiAl}_{2} \mathrm{O}_{4}$, followed by subsequent free sintering or hot pressing avoids the wetting issue, but complicates densification. $[6,7,10,11]$ Also, the hot pressing of sol-gel derived powders has been successfully used to form $\mathrm{Al}_{2} \mathrm{O}_{3}-\mathrm{Ni}$ composites with $\mathrm{Ni}$ contents up to 50 vol.\%.[12] In fact, one of the highest reported toughness for any of these methods was $8.3 \mathrm{MPa} \cdot \mathrm{m}^{1 / 2}$ for a composite containing $50 \mathrm{vol} . \% \mathrm{Ni}$ prepared by hot pressing sol-gel derived powders. [5]

Although they have received less attention, composites of $\mathrm{Al}_{2} \mathrm{O}_{3}$ and $\mathrm{Nb}$ are particularly interesting due to a near thermal expansion match between the two. $\mathrm{Al}_{2} \mathrm{O}_{3}-\mathrm{Nb}$ composites have been formed by sintering of attrition milled $\mathrm{Nb}$ and $\mathrm{Al}_{2} \mathrm{O}_{3}$ powders in vacuum at $1550^{\circ} \mathrm{C}$. $[13,14]$ A composite consisting of 30 volume percent $\mathrm{Nb}$ had a strength of $530 \mathrm{MPa}$, a hardness of $15 \mathrm{GPa}$ and a toughness of $4.5 \mathrm{MPam}^{1 / 2}$. In these composites, the cracks tended to propagate along the $\mathrm{Nb}-\mathrm{Al}_{2} \mathrm{O}_{3}$ interface, forming few bridging ligaments. With few bridging ligaments the composite's toughness was lower than expected based on the metal content and the ductility of $\mathrm{Nb}$.

This work briefly describes the processing of $\mathrm{Al}_{2} \mathrm{O}_{3}-\mathrm{Ni}$ and $\mathrm{Al}_{2} \mathrm{O}_{3}-\mathrm{Nb}$ composites by reactive hot pressing. The elastic modulus, hardness, strength and toughness were measured and the mechanical performance was correlated with the observed microstructures. The high strength and toughness of the $\mathrm{Al}_{2} \mathrm{O}_{3}-\mathrm{Ni}$ composites are of particular note.

\section{PROCESSING}

$\mathrm{Al}_{2} \mathrm{O}_{3}-\mathrm{Ni}$ and $\mathrm{Al}_{2} \mathrm{O}_{3}-\mathrm{Nb}$ composites were prepared by reactive hot pressing metal and ceramic powder mixtures. Two different displacement reactions were used to form these alumina-based composites. Each reaction was thermodynamically favorable; that is, the Gibbs energy change associated with conversion of the reactants to the products was strongly negative. It was important to maintain a very low partial pressure of oxygen during the reaction to 
limit oxidation of the Al. In addition, heat input to the reactants during processing was regulated to prevent the ignition of a self-propagating high-temperature synthesis reaction. The stoichiometries of the displacement reactions are given in Reactions 1-2.

$$
\begin{gathered}
2 \mathrm{Al}+3 \mathrm{NiO} \rightarrow \mathrm{Al}_{2} \mathrm{O}_{3}+3 \mathrm{Ni} \\
10 \mathrm{Al}+3 \mathrm{Nb}_{2} \mathrm{O}_{5} \rightarrow 5 \mathrm{Al}_{2} \mathrm{O}_{3}+6 \mathrm{Nb}
\end{gathered}
$$

The milling, drying, and hot pressing procedures were the same for all compositions.

Precursor powders were mixed ánd ground by attrition milling (Model 01$\mathrm{HD}$, Union Process, Akron, $\mathrm{OH}$ ) in methanol with $3 \mathrm{~mm}$ zirconia media for one hour at $600 \mathrm{rpm}$. The slurry was air-dried and then lightly ground using a mortar and pestle, after which the powders were passed through a 35 mesh sieve.

The precursor powders were hot pressed in graphite dies that were spraycoated with BN (Cerac, Inc., Milwaukee, WI) to limit reaction with the powders. The hot press chamber was evacuated to $10^{-2}$ torr and back-filled with ulta high purity argon gas. This process was repeated three times. The hot press was heated at $1^{\circ} \mathrm{C} / \mathrm{min}$ to $1450^{\circ} \mathrm{C}$, after which a pressure of $34.5 \mathrm{MPa}(5000 \mathrm{psi})$ was applied to the die. The temperature was held at $1450^{\circ} \mathrm{C}$ for 30 minutes, then the furnace was cooled at $20^{\circ} \mathrm{C} / \mathrm{min}$. The pressure was released after the die temperature was less than $300^{\circ} \mathrm{C}$.

In general, dense composites that were completely reacted did not adhere to the graphite. The density of the hot pressed billets was calculated using Archimedes' technique with water as the immersion/saturation fluid. Billets were machined (Chand Kare Technical Ceramics, Worchester, MA) into size B ( 3 by 4 by $45 \mathrm{~mm}$ ) bend bars. Strength was determined in four-point loading. Fracture toughness was measured using the single edge v-notch beam method.[15] Size B beams were fractured in four-point loading. Modulus was measured using a pulseecho technique, and hardness was determined by Vicker's indentation with loads ranging from 5 to $10 \mathrm{~kg}$. Polished cross sections, indented samples, and fracture surfaces were examined by scanning electron microscopy. 


\section{RESULTS AND DISCUSSION}

\section{$\mathrm{Al}_{2} \mathrm{O}_{3}-\mathrm{Ni}$ Composites}

$\mathrm{Al}_{2} \mathrm{O}_{3}-\mathrm{Ni}$ composites were prepared by the reactive hot pressing of $\mathrm{NiO}$ and $\mathrm{Al}$ powders batched with the stoichiometry of Reaction 1 . From Reaction 1, a composite composition of 56 vol. $\% \mathrm{Al}_{2} \mathrm{O}_{3}$ and 44 vol. $\% \mathrm{Ni}$ was predicted. However, the actual metal contents were less because a small amount of $\mathrm{Ni}$ squeezed out of the die during hot pressing. Knowing the initial mass of the reactants, the predicted final composition and thethe mass of $\mathrm{Ni}$ exuded, the composites were estimated to contain around 35 vol.\% Ni. The predicted density of this composition is $5.70 \mathrm{~g} / \mathrm{cm}^{3}$, based on a Ni density of $8.9 \mathrm{~g} / \mathrm{cm}^{3}$ and an alumina density of $3.98 \mathrm{~g} / \mathrm{cm}^{3}$. The composite density measured, by Archimedes' technique was $5.52 \mathrm{~g} / \mathrm{cm}^{3}$, or $97 \%$ relative density. The mechanical properties of $\mathrm{Al}_{2} \mathrm{O}_{3}-\mathrm{Ni}$ composites are summarized in Table $\mathrm{I}$. This composite has an unusually high combination of strength and toughness with strength values of 610 $\mathrm{MPa}$ and toughness of $12.1 \mathrm{MPa} \cdot \mathrm{m}^{1 / 2}$.

Examination of polished cross sections revealed a bimodal size distribution for $\mathrm{Ni}$ inclusions. $\mathrm{Ni}$ ligaments approximately $5 \mu \mathrm{m}$ in width were observed as were smaller $\mathrm{Ni}$ inclusions of $\sim 1 \mu \mathrm{m}$. Indentation cracks show evidence of bridging by intact $\mathrm{Ni}$ ligaments (Fig. 1). Cracks are not seen to travel preferentially along the $\mathrm{Ni}-\mathrm{Al}_{2} \mathrm{O}_{3}$ interface, as has been observed in previous works. $[6,7,10]$ The formation of bridging ligaments indicates a relatively strong bond between the $\mathrm{Ni}$ and $\mathrm{Al}_{2} \mathrm{O}_{3}$. SEM examination of the fracture surfaces shows that the Ni ligaments have been ductily deformed resulting in knife-edges (Fig. 2). Knife-edging is another indication that the Ni reinforcement produces bridging ligaments during crack propagation. The bridging ligaments reduce the stress intensity at the crack tip, thus enhancing the material's toughness.

\section{$\mathrm{Al}_{2} \mathrm{O}_{3}-\mathrm{Nb}$ Composites}

$\mathrm{Nb}_{2} \mathrm{O}_{5}$ and $\mathrm{Al}$ powder mixtures were hot pressed to produce $\mathrm{Al}_{2} \mathrm{O}_{3}-\mathrm{Nb}$ composites. From the stoichiometry of Reaction 2, a composite composition of $34 \mathrm{vol} . \% \mathrm{Nb}$ and $66 \mathrm{vol} . \%$ alumina is predicted. The predicted density of these composites is $5.52 \mathrm{~g} / \mathrm{cm}^{3}$ based on densities of $3.98 \mathrm{~g} / \mathrm{cm}^{3}$ for alumina and 8.57 $\mathrm{g} / \mathrm{cm}^{3}$ for $\mathrm{Nb}$. The density of hot pressed composites was $5.45 \mathrm{~g} / \mathrm{cm}^{3}$, or about $98 \%$ of theoretical. The composite properties are summarized in Table I. This composite had a moderately high strength, $525 \mathrm{MPa}$, but a toughness of only 6.2 $\mathrm{MPa}^{1 / 2}$. The toughness was lower than expected, based on results of the $\mathrm{Ni}$ containing composites. 


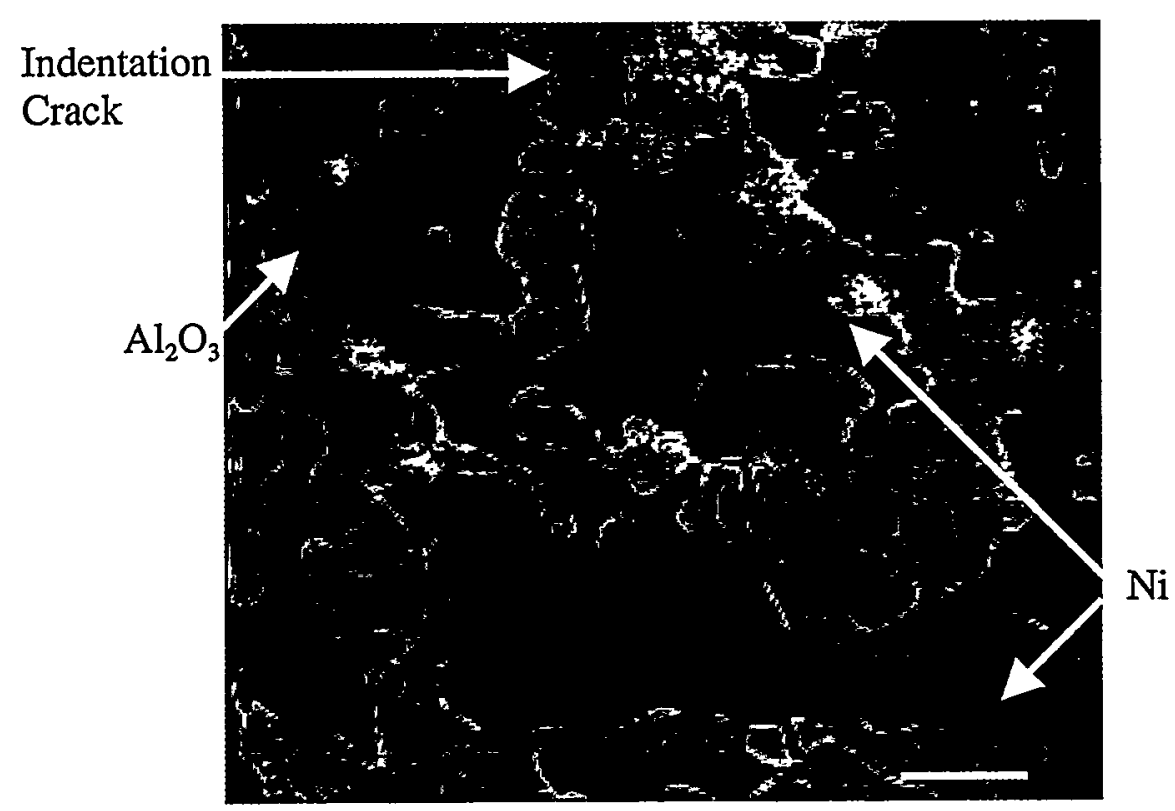

Figure 1. SEM micrograph showing an indentation crack in a composite of $\mathrm{Al}_{2} \mathrm{O}_{3}$ and $\mathrm{Ni}$.

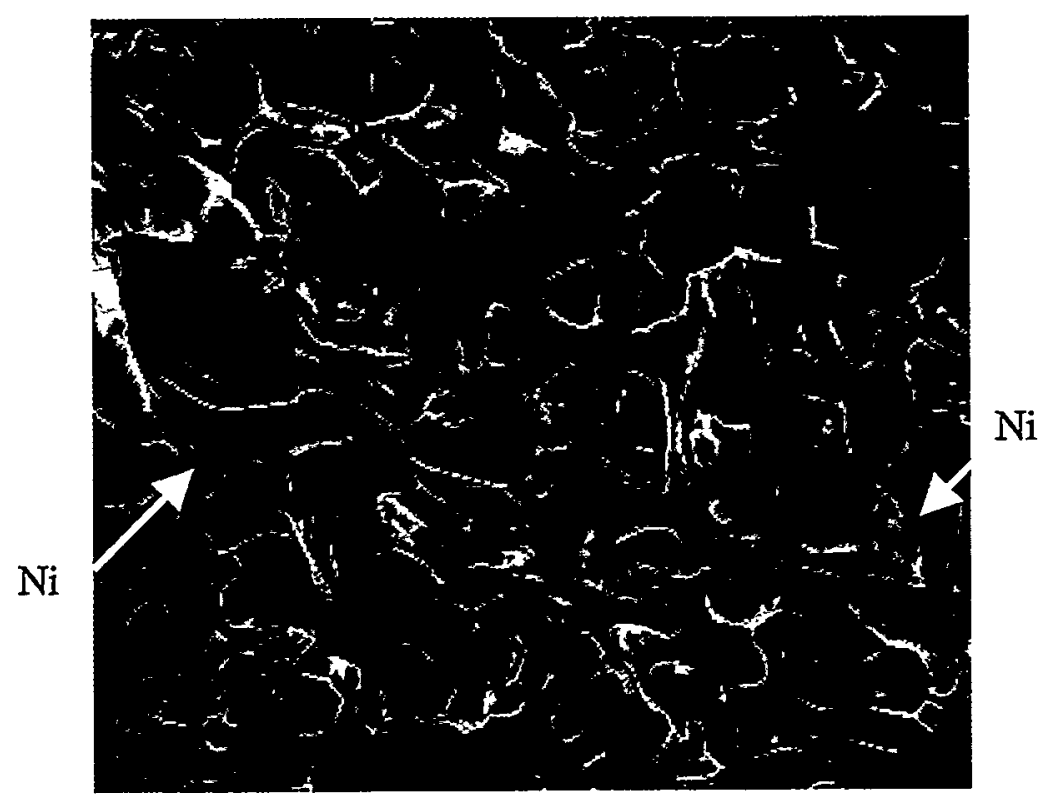

Figure 2. SEM micrograph showing the fracture surface of an $\mathrm{Al}_{2} \mathrm{O}_{3}-\mathrm{Ni}$ composite. 
Examination of the microstructure of a polished cross sectionafter hardness testing (Fig. 3) revealed that the indentation crack traveled preferentially along the ceramic-metal boundary. Few bridging metal ligaments were found, indicating poor adhesion at the ceramic-metal interface. Poor adhesion is probably the reason for the lower toughness. With such poor adhesion bridging metal ligaments do not form, thus the metal phase is not deformed and does not absorb energy during fracture. Such preferential propagation of cracks along the ceramic-metal interfaces has been observed for low toughness composites in previous studies.[5-13]

Table I. Mechanical Properties of Composites.

\begin{tabular}{cccccc}
\hline & $\begin{array}{c}\mathbf{V}_{\mathbf{f}} \text { Metal } \\
(\%)\end{array}$ & $\begin{array}{c}\text { Strength } \\
(\mathbf{M P a})\end{array}$ & $\begin{array}{c}\text { Toughness } \\
\left(\mathbf{M P a} \cdot \mathbf{m}^{\mathbf{1} / \mathbf{2}}\right)\end{array}$ & $\begin{array}{c}\text { Modulus } \\
(\mathbf{G P a})\end{array}$ & $\begin{array}{c}\mathbf{H V} \\
(\mathbf{G P a})\end{array}$ \\
$\mathrm{Al}_{\mathbf{2}} \mathbf{O}_{\mathbf{3}}-\mathrm{Ni}$ & 35 & 610 & 12.1 & 292 & 5.3 \\
$\mathrm{Al}_{2} \mathbf{O}_{\mathbf{3}}-\mathbf{N b}$ & 34 & 525 & 6.2 & 284 & 9.4 \\
\hline
\end{tabular}

\section{SUMMARY}

Thermodynamically favorable displacement reactions were used to form ceramic-metal composites using reactive hot pressing. Metal and ceramic powder mixtures were attrition milled and then hot pressed at $1450^{\circ} \mathrm{C}$ and $34.5 \mathrm{MPa}$. Composites had relative densities of $95 \%$ or greater. $\mathrm{Al}_{2} \mathrm{O}_{3}-\mathrm{Ni}$ composites had an impressively high combination of strength and toughness. Examination of indentation cracks and fracture surfaces showed evidence of ductile deformation of $\mathrm{Ni}$ ligaments during fracture. $\mathrm{Al}_{2} \mathrm{O}_{3}-\mathrm{Nb}$ composites had high strength, although toughness values were lower than expected, possibly due to poor adhesion at the ceramic-metal interface.

\section{ACKNOWLEDGEMENTS}

The authors wish to thank John Geiske of Sandia National Laboratories for performing the modulus measurements. This work was supported by the Advanced Industrial Materials Program in the Office of Industrial Technology at the U.S. Department of Energy (DOE). Sandia is a multi-program laboratory operated by Sandia Corporation, a Lockheed-Martin Company, for the U.S. DOE under contract number DE-AC04-94AL85000. 


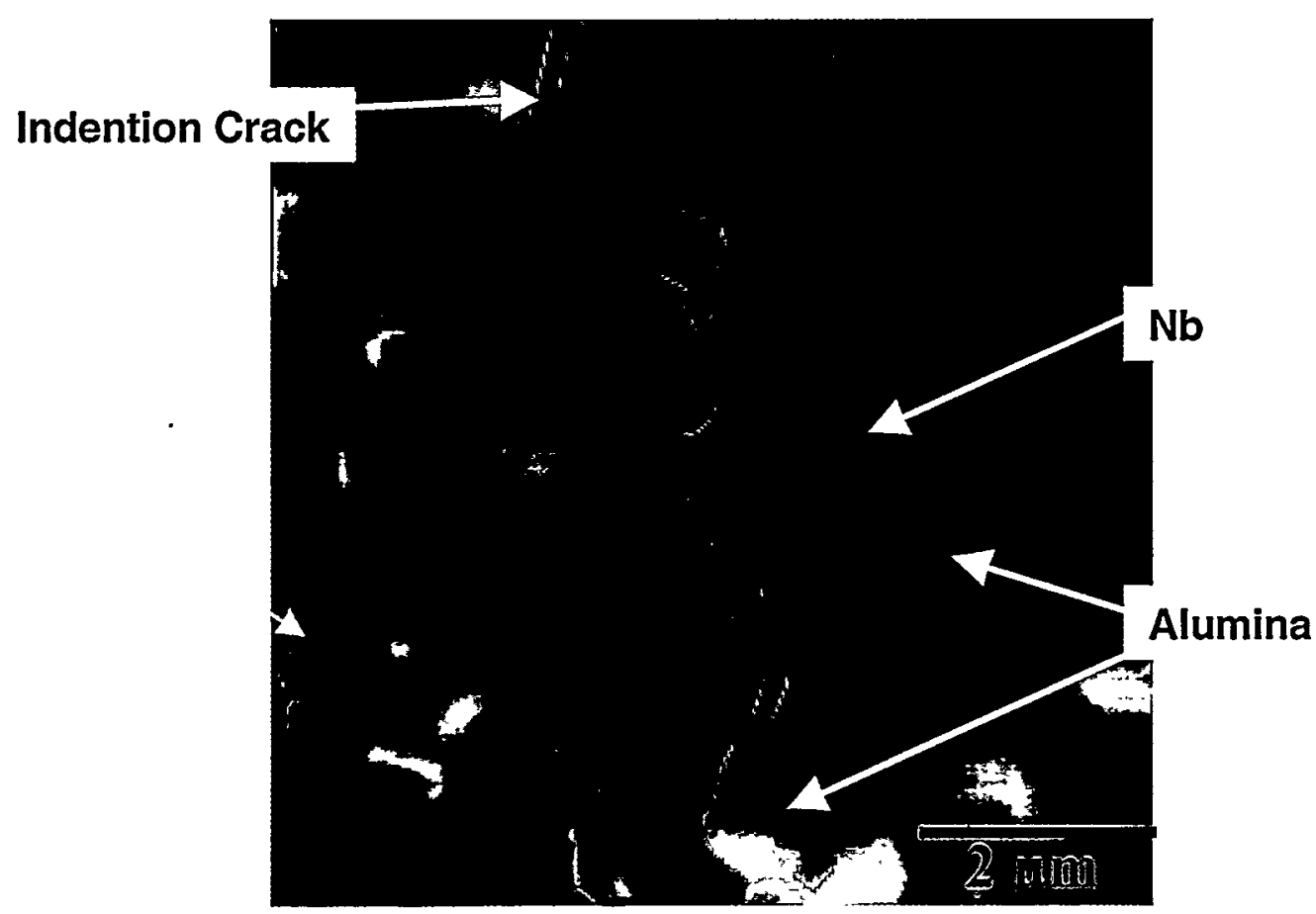

Figure 3. SEM micrograph showing an indentation crack in a composite of $\mathrm{Al}_{2} \mathrm{O}_{3}$ and $\mathrm{Nb}$.

\section{REFERENCES}

1. M.K. Aghajanian, N.H. Macmillan, C.R. Kennedy, S.J. Luszcz, and R. Roy, "Properties and Microstructures of Lanxide $\mathrm{Al}_{2} \mathrm{O}_{3}$-Al Ceramic Composite Materials," Journal of Materials Science, 24 658-670, (1989).

2. R.E. Loehman, K.G. Ewsuk, and A.P. Tomsia, "Synthesis of $\mathrm{Al}_{2} \mathrm{O}_{3}-\mathrm{Al}$ Composites by Reactive Metal Penetration," Journal of the American Ceramic Society, 79(1) 27-32, (1996).

3. M.C. Breslin, J. Ringnalda, L. Xu, M. Fuller, J. Seeger, G.S. Daehn, T. Otani, and H.L. Fraser, "Processing, Microstructure, and Properties of CoContinuous Alumina-Aluminum Composites," Materials Science and Engineering A, A195 113-119, (1995).

4. H. Prielipp, M. Knechtel, N. Claussen, S. K. Streiffer, H. Mullejans, M. Ruhle, and J. Rödel, "Strength and Fracture Toughness of Aluminum/Alumina Composites with Interpenetrat " Materials Science and Engineering A, A197 19-30, (1995). 
5. E. Breval, Z. Deng, S. Chiou, and C.G. Pantano "Sol-Gel Prepared Nialumina Composite Materials Part 1 Microstructure and Mechanical Properties," Journal of Materials Science, 27 1464-1468, (1992).

6. W.H. Tuan and R.J. Brook, "The Toughening of Alumina with Nickel Inclusions," Journal of the European Ceramic Society, 6 31-37, (1990).

7. W. H. Tuan, M.C. Lin, and H.H. Wu, "Preparation of $\mathrm{Al}_{2} \mathrm{O}_{3} / \mathrm{Ni}$ Composites by Pressureless Sintering in $\mathrm{H}_{2}$," Ceramics International, 21. 221-225, (1995).

8. S. A. Jones, J.M. Burlitch, E. Üstündag, J. Yoo and A.T. Zehnder "NickelAlumina Composites: In Situ Synthesis by a Displacement Reaction, and Mechanical Properties," Materials Research Society Symposium Proceedings, 365 53-58, (1995).

9. E. Üstündag, P. Ret, Y. Shapiro, R. Subramanian, R. Dieckmann, and S.L. Sass "Ductile Phase Toughened Ceramics by Partial Reduction Reactions in the Ni-Al-O System: Mechanical Properties and Effect of Dopants," Materials Research Symposium Proceedings, 365125-130, (1995).

10. T. Sekino, T. Nakajima, S. Ueda, and K. Niihara "Reduction and Sintering of a Nickel-Dispersed-Alumina Composite and Its Properties, "Journal of the American Ceramic Society, 80(5) 1139-1148 (1997).

11. W.H. Tuan, H.H. Wu, and R.Z. Chen, "Effect of Sintering Atmosphere on the Mechanical Properties of $\mathrm{Ni} / \mathrm{Al}_{2} \mathrm{O}_{3}$ Composites," Journal of the European Ceramic Society, 17 735-741, (1997).

12. E. D. Rodeghiero, B.C. Moore, B.S. Wolkenberg, M. Wuthenow, O.K. Tse, and E.P. Giannelis "Sol-Gel Synthesis of Ceramic Matrix Composites," Materials Science and Engineering, A244 11-21, (1998).

13. D.E. Garcia, S. Schicker, J. Bruhn, R. Janssen, and N. Claussen "Processing and Mechanical Properties of Pressureless-Sintered Niobium-AluminaMatrix Composites, "Journal of the American Ceramic Society, 81(2) 429432, (1998).

14. D.E. Garcia, S. Schicker, R. Janssen, and N. Claussen "Nb- and $\mathrm{Cr}-\mathrm{Al}_{2} \mathrm{O}_{3}$ Composites with Interpenetrating Networks," Journal of the European Ceramic Society, 18 601-605, (1998).

15. J. Kuebler, "Fracture Toughness of Ceramics Using the SEVNB Method: Preliminary Results, " Ceramic Engineering and Science Proceedings, 18(4) p. $155-162$ (1997). 